\title{
"The Singing Building" in the Ryazan Kremlin (XVII-XVIII Centuries): A Strategy for Preserving the Object of Cultural Heritage
}

\author{
Marina V. Knyazeva ${ }^{1}$, Sergey V. Mokhovikov ${ }^{2,3}$, Lidiya V. Alekseenko ${ }^{4, *}$, Natalia S. Bryazgunova ${ }^{5}$, \\ Genadiy B. Baranov ${ }^{2}$

\begin{abstract}
${ }^{1}$ Department of Architecture and Urban Planning, Member of the Union of Designers of Russia, Ryazan Institute (branch) of the Moscow Polytechnic University, Russia

${ }^{2}$ Department of Architecture and Urban Planning, Ryazan Institute (branch) of the Moscow Polytechnic University, Russia Museum-Reserve, Russia Moscow Polytechnic University, Russia
\end{abstract} \\ ${ }^{3}$ Deputy Director for Construction and Restoration, Federal State Budgetary Institution of Culture Ryazan Historical and Architectural \\ ${ }^{4}$ Department of Architecture and Urban Planning, Member of the Union of Mine Surveyors of Russia, Ryazan Institute (branch) of the \\ ${ }^{5}$ Department of Engineering Business and Management, Ryazan Institute (branch) of the Moscow Polytechnic University, Russia
}

Received October 12, 2020; Revised December 23, 2020; Accepted January 20, 2021

\section{Cite This Paper in the following Citation Styles}

(a): [1] Marina V. Knyazeva, Sergey V. Mokhovikov, Lidiya V. Alekseenko, Natalia S. Bryazgunova, Genadiy B. Baranov, "'The Singing Building" in the Ryazan Kremlin (XVII-XVIII Centuries): A Strategy for Preserving the Object of Cultural Heritage," Civil Engineering and Architecture, Vol. 9, No. 1, pp. 130-138, 2021. DOI: 10.13189/cea.2021.090111.

(b): Marina V. Knyazeva, Sergey V. Mokhovikov, Lidiya V. Alekseenko, Natalia S. Bryazgunova, Genadiy B. Baranov (2021). "The Singing Building" in the Ryazan Kremlin (XVII-XVIII Centuries): A Strategy for Preserving the Object of Cultural Heritage. Civil Engineering and Architecture, 9(1), 130-138. DOI: 10.13189/cea.2021.090111.

Copyright $\odot 2021$ by authors, all rights reserved. Authors agree that this article remains permanently open access under the terms of the Creative Commons Attribution License 4.0 International License

\begin{abstract}
Introduction: The Ryazan Kremlin is a unique architectural open-air museum-reserve. The importance of the Ryazan Kremlin in the town-planning system of the city is associated with its historical significance. It is the oldest part of Pereyaslavl-Ryazan. The architecture of the Ryazan Kremlin is represented by 17 monuments of history, culture and architecture of federal significance. Among them is the "Singing Building", which is a traditional example of civil architecture before Peter the Great. Purpose of the research: Determination of conditions and factors creating prerequisites for the destruction of historical and architectural monuments. Creation of an effective mechanism to ensure the safety of the cultural heritage site. Research methods: The research involved the work of domestic and foreign authors. Analysis of the works showed an insufficient degree of study of the problem. The article presents historical and archival data on the architectural monument of federal significance, presents the methods and methods provided by the project for the restoration, preservation and restoration of the decor of the
\end{abstract}

facades, which have losses with their painting. The main repair and restoration work and their sequence for preserving the cultural heritage object - the building of the "Singing Building", which is one of the iconic and representative buildings built in the middle of the 17th century, is described in the eastern part of the territory of the "Archbishop" yard of the Ryazan Kremlin. Results: Based on historical information about the cultural heritage object and its technical condition, including the territory occupied by the object, small architectural forms, monumental painting and interior decoration items, engineering structures and equipment, an analysis of the current state of the monument was carried out and a project of restoration work on the facades and interiors of the building was developed.

Keywords Architectural Monument, Restoration Work, Preservation of Historical and Cultural Heritage, Complex Scientific Research, Ryazan Kremlin, Ryazan, Russia 


\section{Introduction}

Ryazan is an ancient city, one of the oldest centers of Russian culture [1, P. 5]. Ryazan was founded in 1905. Its architectural originality, which has been formed over the centuries, is determined by a large number of objects of historical and cultural heritage. There are 296 monuments (history, architecture and archeology) and 1 object that have the characteristics of cultural heritage objects on the territory of the city [2].

However, there is a threat of loss of historical and architectural monuments due to poor preservation of many buildings and improper operation. Many cultural heritage sites are located in the historical part of the city. The problem of maintenance and preservation of such buildings is one of the most urgent at the present stage of development of society. The lack of proper attention from both the authorities and the public to the problem of preserving historical buildings can have a disastrous effect on both the material and spiritual spheres of human life [3, 4].

The problem of studying and preserving historical and cultural heritage is one of the most pressing issues of our time for the successful development of historical cities. The preservation of cultural heritage objects is guaranteed by current legislation in the interests of the multi-ethnic people of the Russian Federation (Federal law No. 73-FZ of 25.06.2002). According to the current legislation, real estate objects with historically related "works of painting, sculpture ,decorative and applied art, objects of science and technology and other items of material culture that arose as a result of historical events, are of value from the point of view of history, archeology, architecture, urban planning, art, science and technology, aesthetics, Ethnology or anthropology, social culture, and are evidence of epochs and civilizations, authentic sources of information about the origin and development of culture" [5] are considered objects of cultural heritage.

\section{The Degree of Problem Research}

A comprehensive study of the protection of cultural heritage at the state level in national historiography is given attention in the articles of T.A. Molokova [6], A.F. Belozer [7], V.I. Melekhov, L. G. Shapovalov [8].

When studying architectural monuments, the researchers should pay attention to the historical environment of the city. The preservation of cultural heritage as the preservation of the high-quality urban environment of the historical city can be traced in the works of N.A. Leshchenko [9]. The work showing a comparative analysis of projects for the preservation and development of historical territories of different years on the example of Usolye is of great interest [10]. The assessment of the review showed that all projects are aimed at preserving the object of cultural heritage, but there is no vision of the strategic development of the territory [11].

The subject of study in the works of foreign scientists P. Marcuse, R. van Kempen [12], R. Venturi, D. Scott Brown [13] was the appeal to the issues of regeneration and protection of the historical environment, and in a number of articles by other foreign researchers, the problems of studying the modern urban culture in the context of historical development and preservation of architectural heritage $[14,15,16]$

The theme of preserving historical buildings and cultural heritage sites at the regional level was reflected in the works of O.R. Denisenkova [17], S.A. Pyatachenko, A.G. Karpenko, T.M. Potokin [18], K.A. Mikhaleva [19], L.S. Paramonova [20], Zh.T. Talanbekova, Zh.Y. Mamatov [21].

Concerning the Ryazan region, these problems found their expression in a number of studies by D.D., Duzhik, A.A. Kozhnova [22], A.A. Pankratova [23], A.K. Solovyova [24], N.A. Osina, E.N. Melnikova [25], N.A. Osina, L.A. Zhuravleva, V.A. Chevagina [26], M.V. Knyazeva, D.V. Evtyukhina, V.K. Melnikova [27], S.V. Mokhovikov, L.V. Alekseenko, M.V. Knyazeva, I.A. Murog, O.S. Larina [28].

\section{Problem}

Any historical and architectural monument performs the function of fixing its time for future generations. In order to study the historical and cultural heritage, it is necessary to draw up a historical portrait of the building, to study its architectural and constructive-technical features [6, P.1-2].

When performing any work on the preservation of a historic building, it should be considered as a complex combined work of art [29]. Renovation and restoration work involves a complex research and production process, in which attention should be paid to external elements, interior space and decoration. To carry out high-quality work, it is necessary to develop a list of repair and restoration work and a scientifically based choice of materials for restoration and protection from external influences.

The architectural monument of the XVII Singing building in the Ryazan Kremlin was chosen for the study of the cultural heritage object. Historical and architectural and artistic buildings that are part of the ensemble of the Ryazan Kremlin - the oldest part of the city, which every citizen of Ryazan knows, is a symbol of the city. The singing building in the architectural and historical ensemble of the Ryazan Kremlin (Fig. 1) occupies a deservedly worthy place. It is a traditional example of civil architecture before Peter the Great and is extremely interesting for its preserved examples of interior wall paintings of that time. 


\section{Schematic plan of the Ryazan Kremlin}

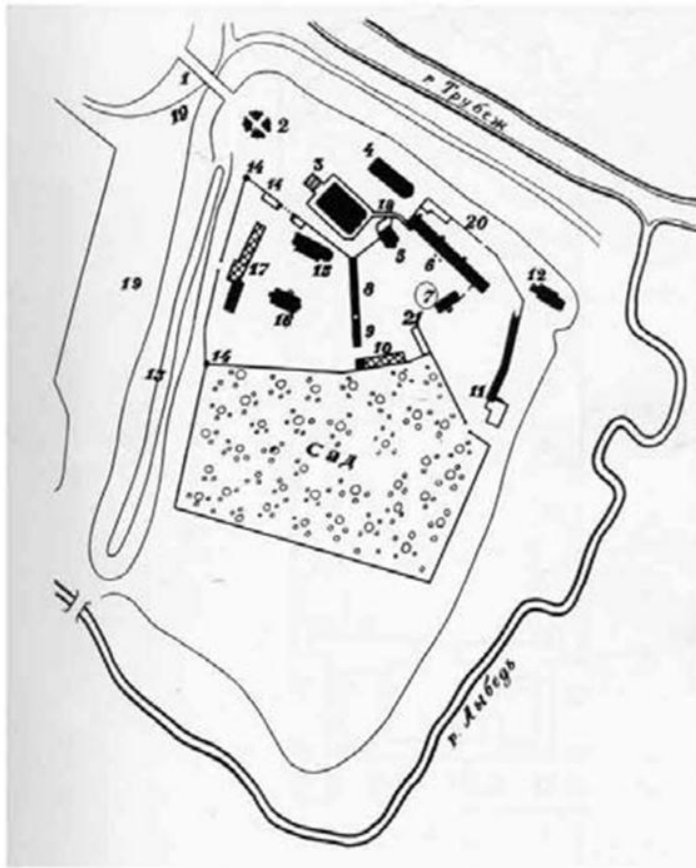

1 - bridge, 2 - bell tower, 3 - Assumption Cathedral, 4 - Nativity of Christ Cathedral (old Assumption Cathedral ), 5 - Archangel Cathedral, 6 - Bishop's house. 7 - Singing building, 8 - Consistory building, 9 - Sheds for different luggage, smithy, bocharnaya, 10 - stable and carriage shed, 11 - barns (" hotel of the poor"), 12 - Church of the Holy Spirit, 13 - rampart, 14 - fence of the Spassky monastery, 15 - Church of the Epiphany, 16 - Spaso-Preobrazhensky Cathedral, 17 - "hotel of the nobility" ,18 - transition, 19 - moal, 20 - city of the Bishops' court

Figure 1. Archived schematic plan of the Ryazan Kremlin

The singing building belongs to the category: An architectural monument of federal significance on the basis of the Resolution of the Council of Ministers of the RSFSR No. 1327 of 08/30/1960. The building is used to house a permanent museum exhibition and changing exhibitions.

\subsection{Brief Historical Information}

The singing building in the Ryazan Kremlin was built in the middle of the 17th century, presumably in 1658 [30, p. 644] (Fig. 2). Its author may have been Yu.K. Yarshov, an architect of the "stone affairs apprentice" from Moscow of the "Zayaguzhskaya settlement of Teglets" [1, pp. 87-88] (spelling as Y.K. Ershov is also in the literature).

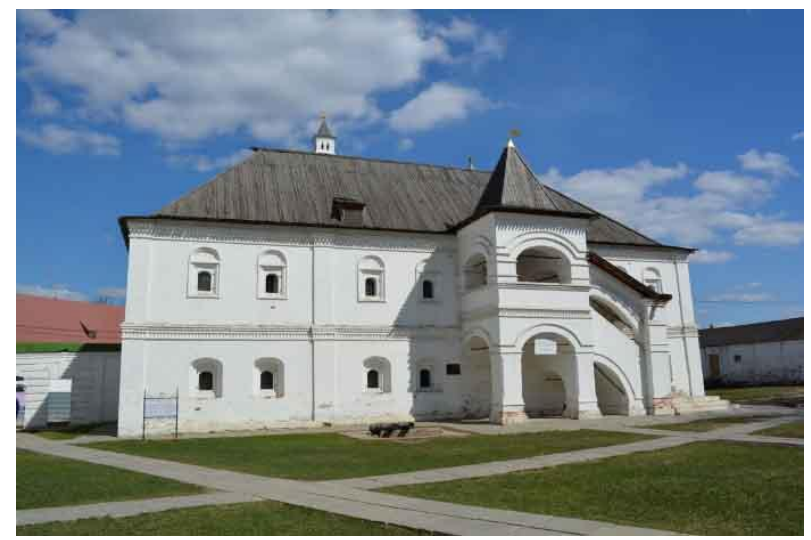

Figure 2. Singing building in the Ryazan Kremlin

The Singing building got its name from the rehearsals conducted by the singers, in a special chamber allocated for them. The main purpose of the building was different. It housed living quarters for bishops - the housekeeper and the treasurer. The receptionist of the housekeeper was located in the southeastern room of the 1st floor.

The building is a two-story brick building of civil architecture. The "typical" residential section of the 17th century, consisting of cold canopies and adjacent warm canopies at right angles, both on the first and second floors, is used for the building. Two doors from the warm hallway lead to two isolated chambers, located side by side and with windows, overlooking the main facade.

A small two-story tent - a retreat is attached in the opposite side of the main entrance to the cold canopy. A small kitchen was located on the ground floor on the other side of the dwelling, with an entrance directly from the cold hallway (Fig. 3). 


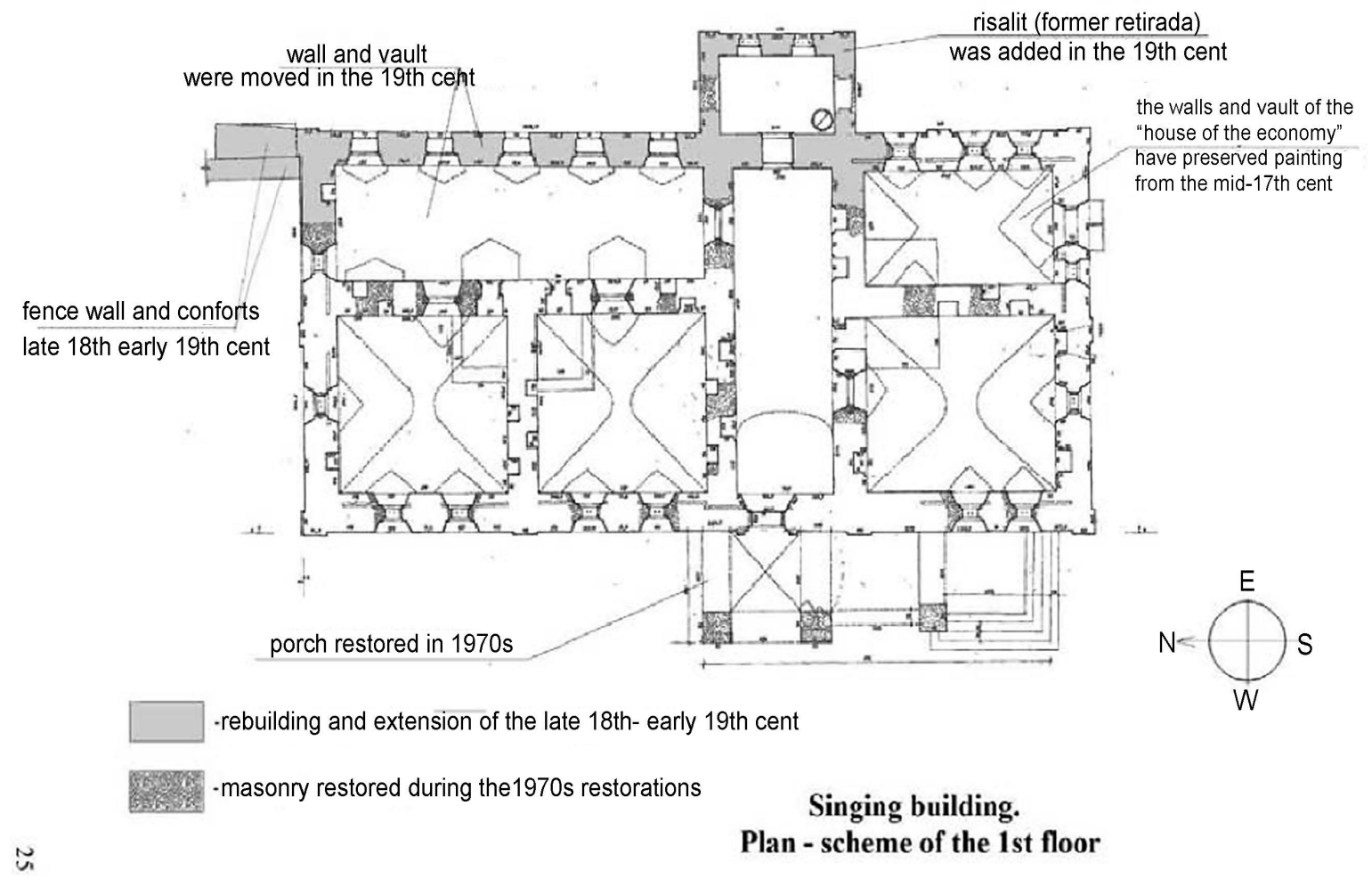

Figure 3. Singing Building. 1st floor plan

The reception room adjacent to the kitchen had a separate entrance from the street. Significant fragments of the unique original wall ornamental paintings have been preserved in the reception room (Fig. 4).

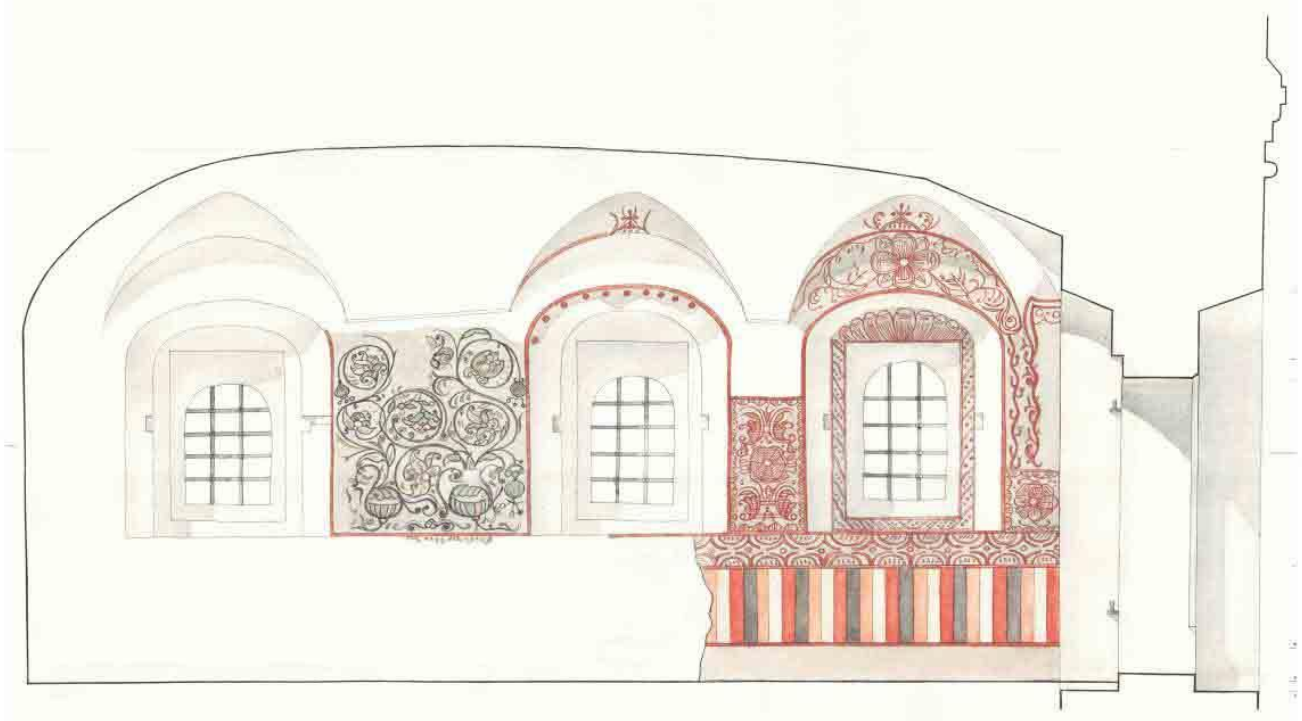

1-й этаж Певческого корпуса. Роспись сер.XVII в. на восточной стене "палаты эконома". Чертеж из архива ГУП ЦНРПМ.

ส

Figure 4. 1st floor of the Singing Building. Painting of the middle of the 18th century on the East wall of the "House of the housekeeper» 


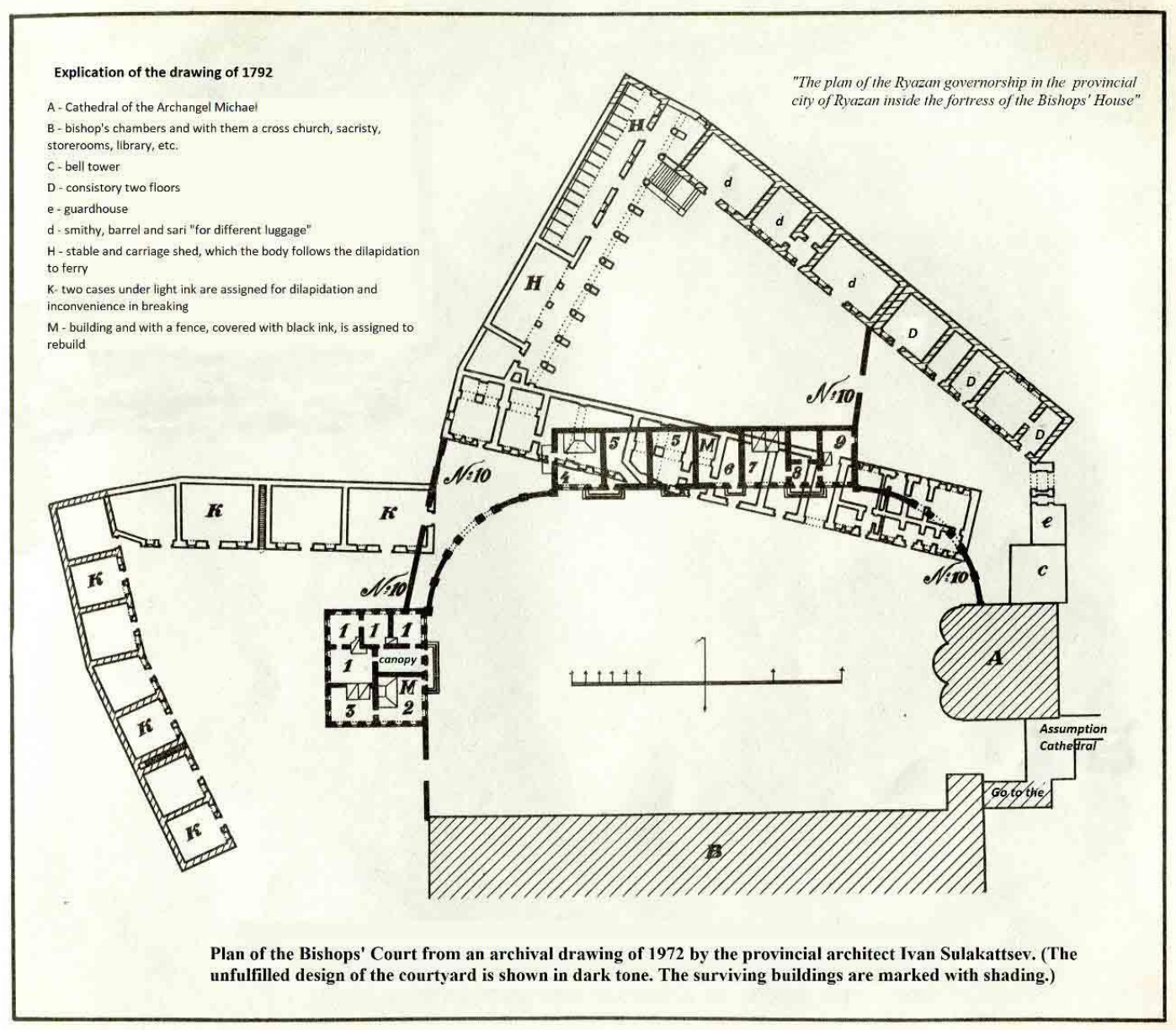

Figure 5. Plan - a drawing of the new building of the housekeeper made by the architect I. Sulakadzev

In the 18th century, the building was badly dilapidated and at one time it was even planned for complete dismantling. The construction of a new building for the housekeeper was planned at a different place, in the eastern part of the Bishops' court according to the drawings of the Ryazan provincial architect I. Sulakadzev (Fig. 5) ${ }^{1}$.

However, at the end of the 18th century, the building was nevertheless renovated with a change in the architecture of the facades in a new form. At the same time, the two-tiered porch of the western facade was dismantled. All window and door openings were redone,

\footnotetext{
1 Sulakadzev Ivan Grigorievich (1741-1821), Ryazan provincial architect, who served in Ryazan province from 1782 to 1808 . He graduated from the Raznochinsky gymnasium at Moscow University. (Note by M.V. Knyazeva). Also about him: Knyazeva M.V. Professional activity and architectural creativity of the Ryazan provincial architects in the context of the implementation of urban planning reform (1780-1860) // Izvestia of the Kazan State University of Architecture and Civil Engineering. 2019.No. 1 (47) S. 26-35; Knyazeva M.V. The history of general planning of a provincial Russian city: ideas and implementation (1780-1991) on the example of Ryazan: dissertation ... Candidate of Historical Sciences: 07.00.02 / Moscow State Regional University. Ryazan, 2013.
}

except for three, which are almost completely preserved. Obviously, at the same time, between the northern facade and the Bishops' House, a fence wall with a gate and a wicket appeared.

A new retreat was built on the site of the old one and the north-eastern part of the wall of the courtyard (eastern) facade was rebuilt, the roof was lowered and covered with iron in the 19th century.

At the end of the 19th century, a one-story stone vestibule was built on the site of the main part of the ancient two-story porch; it was demolished by the architect Z.I. Vasilyeva in 1958. After the demolition of the outer porch in the 19th century, an internal wooden staircase leading to the second floor was built in the main hallway, while the original vault was partially broken.

The wall of the eastern facade has a risalit (retirada) in the center, added in the 19th century and completed by a pediment. The main entrance to the building with a two-storey porch is located on the side of the western facade.

Most of the small arched windows on the first floor are located in deep, similarly shaped niches, without 
plat-bands. The windows of the second floor are framed with rectangular plat-bands with semicircular completion [31, P. 35].

\subsection{Assessment of the Existing Technical Condition of the Monument}

In order to assess the existing state of the architectural monument, it is necessary to examine the building. As a result, the assessment of the building of the Singing Building was based on a visual inspection of the building of external and internal architectural, structural and decorative elements of the object, the monument was fixed with the required measurements, as a result of which damage and defects were identified.

The fixation of a cultural heritage object plays an important role in the preparation of project documentation and its preparation for restoration work. It aims to solve several problems. First of all, it gives an idea of the current state at the time of the study, makes those changes that have occurred during the operation of the monument or since its last restoration. Only fixation makes it possible to understand what has been preserved and what has been lost. Because fixation of objects is carried out by photographing, verbal description and measurements of the building, the latter are included in the basis of the documentation, on the basis of which design drawings are prepared. Thus, a competent and carefully composed description serves as the basis for research and repair and restoration work at the cultural heritage site.

\subsection{The Current State of the Monument}

The description of the outer walls provides for the condition of all parts of the building.
The walls of the building and annexes are spandrel, massive, however, subsidence cracks are observed on the north and west walls at the level of the basement and the lower part of the walls.

This is due to the unsatisfactory condition of the foundations. This is especially noticeable on the eastern facade of the building and the wall of the late 18th and early 19th centuries, connecting the northern part of the Singing Building with the annex of the Bishops' House (Fig. 6).

A plinth is available at all walls of the Singing Building. The profiled basement of the middle of the 17th century was lined with white stone blocks of the basement of the late 18th - early 19th centuries, when work was being carried out to strengthen the foundations. There are traces of a cut fourfold ridge on the base of the eastern facade, and fragments of the original brick profile have been preserved in places (Fig. 6).

The walls were reworked in the 19th century, plastered and painted, but the plaster of the walls has cracks. There are traces of destruction, numerous cracks on the surface of the walls in the lower part.

The finishing (coating and painting) of the facades is in an unsatisfactory condition and requires replacement.

The blind area requires repair.

The walls in the interiors of the first floor are waterlogged, which leads to the destruction of the decoration and wall paintings.

The 17th century wall painting on the walls of the corner southeastern chamber of the first floor of the Singing Building has been preserved in a significant amount (about 40\%) and is of significant artistic and historical interest.

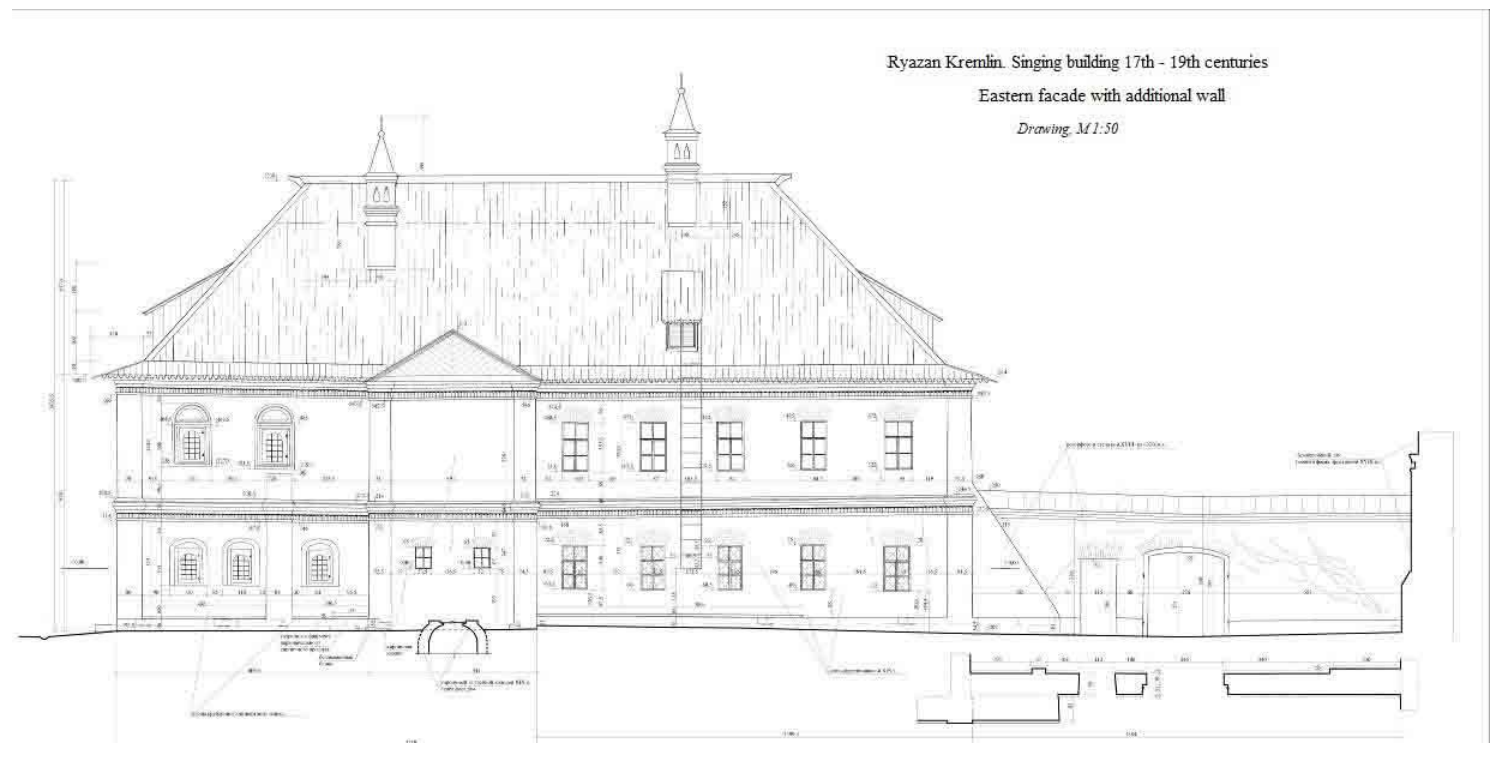

Figure 6. Dimensional drawing. East facade with adjoining wall 


\section{Materials and Research Methods}

This research was carried out on the basis of archival data on the object of cultural heritage, data on restorations of past years.

The research methodology was provided by research work, collection and analysis of archival and historical information, design and production work, previously completed scientific and project documentation, including:

- Archive of the State Unitary Enterprise Central Scientific Restoration Design Workshops: Preliminary work, archive No. 21-P / 5; Report on archaeological research archive No. 21-P / (1981);

- Stereo measurements and hand-held measurements, archive No. 21-P / (1983);

- Draft design of restoration - archive No. 21-P / 72-74,76,78-86 - separate drawings without binding; Report on the conducted research on pits and soundings Archive LLC "RESTEK" Engineering and technical conclusion on the state of foundations (2010);

- Project for waterproofing foundations (2010);

- Technological studies and recommendations for restoration work on the facades (2010);

- Archive of the Ryazan Historical and Architectural Museum-Reserve - Report "Detailed engineering and geological studies at the site of the Singing building" (final), LLC "Firm REMIS", Moscow, 2004.

- Comprehensive studies of the moisture content of walls and microbiological analysis of the state of building materials of walls, aero microbiological study of the air environment in the premises of the Singing Building, Biotechnology and Restoration LLC, 2013

The methodology for carrying out full-scale materials science research included:

- visual inspection of the interior walls of the monument, as well as fragments of brick and white stone masonry of the facades base;

- measurement of moisture content of masonry wall fragments by non-destructive contact method;

- sampling with the identification of areas of damage to the paint layer, plaster, white stone;

- laboratory quantitative and qualitative microbiological analysis of samples of building materials and air;

- inspection of wooden structures.

Sampling of damaged building materials was carried out in two ways: by direct inoculation of surface plaque scraping with a sterile scalpel into sterile Petri dishes with nutrient media to isolate bacteria and mold fungi, and by scraping damaged material into sterile Petri dishes for quantitative laboratory analysis of microorganisms by the method of tenfold dilutions.
Aero microbiological study of the premises was carried out using a highly sensitive electrical sampling device PU-1B (Russia). To assess the general level of microbial contamination of the air, we used the PDH nutrient medium, as well as the Capek medium for the detection of molds. After inoculation, plates and test tubes with media were incubated in a thermostat at a temperature of $25-27^{\circ}$ C.

The moisture content of the plaster layer and brickwork of the walls at a depth of $1 \mathrm{~cm}$ and $4 \mathrm{~cm}$ in the places of sampling was determined by a non-destructive contact method using an electronic moisture meter G810 from Denzel (Germany).

\section{Research Result}

Research and development of the project for the restoration of the monument began under the leadership of the architect I.V. Ilyenko (V / O "Soyuzrestavratsiya", Moscow) in the 1960s.

Windows in the 17th century forms were restored in place of the late windows on the western, southern and northern facades and the southern part of the eastern facade; the upper part of the crown cornice was dismantled during the restoration work in the 1970s under the leadership of I.V. Ilyenko. The brick porch on the western façade was rebuilt following natural traces foundations and abutment marks on the wall.

At the same time, the foundation was laid according to the project of the engineer N.A. Makolov.

In the interior, the ancient layout of the 17th century chambers has been restored, taking into account their adaptation both for exhibitions from the museum's funds and for accommodating employees engaged in scientific work.

Designed by architect I.V. Ilyenko, the tiled stoves were restored in their historical places. In the southeastern chamber of the 1st floor (the former reception room of the housekeeper), a unique original painting of the walls and partially of the vaults was discovered (Fig. 4). Such a painting of the middle of the 17 th century has practically not survived in the buildings of civil architecture in Russia.

The restoration of the painting in the $70 \mathrm{~s}$ of the twentieth century was carried out by highly qualified art restorers Georgy Evgenievich Bryagin and his daughter Tatyana Georgievna Bryagina [30, p. 644].

The high plank wooden roof of the chambers was restored in 2002 and the chimneys in 2010 in accordance with the restoration project.

In the early 2000s, a new painting of walls and vaults in the style of the 17th century was made in the eastern hallways and the northern chamber of the first floor (according to the museum exhibition program). At the same time, on the first floor, a tiled stove was recreated 
from polychrome relief tiles.

As a result of a comprehensive microbiological study of the air microflora of the exhibition halls and auxiliary rooms and building materials of the supporting structures, carried out in June-September 2013, 44 air samples and 44 samples of damaged plaster and paint were taken, as a result of which 22 areas were identified, the most damaged areas.

\section{Finding}

As a result of the conducted surveys, the project of the main repair and restoration works and their order has been drawn up.

The first stage consists of repair and restoration work on facades, strengthening and waterproofing of foundations. The second stage includes work to strengthen the sections of 17th-century paintings in the corner chamber of the first floor, which requires the involvement of a specialized organization to survey the state of 17th-century paintings and artists-restorers for the restoration of paintings.

In order to suspend the processes of biodegradation, it was decided to carry out antimicrobial and antiseptic treatment of the walls and basement, treat it with a biocidal composition.

\section{Conclusions}

The significance of historical and cultural monuments of Ryazan, reflecting the thousand-year history of our region, is obvious and indisputable. Each object of cultural heritage creates a special kind of economic resource that contributes to the development of the region's territory and its infrastructure.

Despite the fact that the economy of cultural heritage operates only with the material concepts of "buildings, structures and monuments inherited from the past, with cultural or historical significance that justifies their preservation for future generations" [32, p. 255], leaving out of focus the intangible aspects (language, traditions, rituals, etc.), it is the monuments of history and culture at each stage of the formation of society that serve as one of the means of educating citizenship, which is expressed in the establishment of their cultural and historical significance. At the same time, looking at modern models of sustainable development of a cultural asset, it is they who "earn" economic resources that are useful for maintaining the object [33].

Historical and architectural monuments are being restored. However, the problem of preserving them remains. Demolitions are not allowed. Any cultural heritage object that is under state protection must be restored and preserved. The main goal of the restoration is not only to preserve the historical building, but also to operate it in modern conditions.

Restoration must be carried out in accordance with current legislation on the basis of the restoration project in accordance with the passport of the object and its features. Proper and competent restoration not only extends the service life of the building, but also helps to avoid repeated repairs, which is undesirable for historical objects.

\section{REFERENCES}

[1] Mikhailovsky, E., Ilyenko I., Ryazan. Kasimov. Moscow, Publishing "Art", 1969, 240 p.

[2] List of objects of cultural heritage, The official website of the government of the Ryazan region, Online available from: https://iokn.ryazangov.ru/activities/spisok-okn/ (accessed 07.07.2020).

[3] Meier, H.-R., Wohlleben, M. (Hrsg.), Bauten und Orte als Träger von Erinnerung, Die Erinnerungsdebatte und die Denkmalpflege, vdf Hochschulverlag AG an der ETH. Zürich, 2000, $230 \mathrm{p}$.

[4] Eckert, H., Kleinmanns, J., Reimers, H.,Denkmalpflege und Bauforschung, Sonderforschungsbereich 315, Universität Karlsruhe (TH), Karlsruhe, 2000, 214 p.

[5] Federal Law "On Cultural Heritage Objects (Historical and Cultural Monuments) of the Peoples of the Russian Federation" of June 25, 2002 N 73-FZ (last edition), Available at: http://www.consultant.ru/document/cons_doc _LAW_37318/(accessed 08.07. 2020).

[6] Molokova, T.A., Preservation of cultural heritage in Russia: a historical review, Society: philosophy, history, culture, 2019, No. 4 (60), P. 83-86.

[7] Belozor, A.F., Cultural heritage as an object of national and regional policy, Scientific Almanac, 2016, No. 2-4 (16), P. 300-305.

[8] Melekhov, V.I., Shapovalova, L.G., Preservation and state protection of objects of cultural heritage of Russia. News of higher educational institutions, Jurisprudence, 2005, No. 3 (260), P. 12-20.

[9] Leshchenko, N.A., Revalorization as a restoration transformation for creating a high-quality urban environment of a historic small town, Bulletin of the Brest State Technical University, Construction and architecture, 2018, No. 1 (109), P. 7-10.

[10] Bushmakova, Yu.V., Safroshenko, ON., Comparative analysis of projects for the preservation and development of historical territories of small cities on the example of Usolye, Bulletin of the Perm National Research Polytechnic University, Applied ecology, Urban studies, 2020, No. 1 (37), P. 16-31.

[11] Herzberg, L. Ya., The potential and real role of scientific research in the innovative development of urban planning activities in Russia, Fundamental, exploratory and applied 
research by the Russian Academy of Architecture and Construction Sciences on the scientific support of the development of architecture, urban planning and the construction industry of the Russian Federation in 2016: collection of scientific papers of the RAASN, Moscow: ASV Publishing House, 2017, Vol. 1, P. 288-297, DOI: 10.22337 / 9785432302205-2017-288-297.

[12] Marcuse, P \& Kempen, R Van. (eds), Of States and Cities: The Partitioning of Urban Space, New York, 2002, 216 p.

[13] Venturi, R \& Scott Brown, D., Architecture as Signs and Systems: For a Mannerist Time, Cambridge, MA, London, 2004, 264 p.

[14] Zhou, S., Zhang, S., Contextualism and sustainability: a community renewal in old city of Beijing. Sustainability, 2015, Vol. 7, Issue 1, Pp. 747-766, Doi: 10.3390 / su7010747

[15] Kiruthiga, K., Thirumaran, K., Effects of urbanization on historical heritage buildings in Kumbakonam, Tamilnadu, India, Frontiers of Architectural Research, 2019, Vol. 8, Issue 1, Pp. 94-105, DOI: 10.1016 / j. foar. 2018.09.002

[16] Lee, S.L., Urban conservation policy and the preservation of historical and cultural heritage, Cities, 1996, Vol. 13, Issue 6, Pp. 399-409, DOI: 10.1016 / 02642751 (96) 00027-3

[17] Denisenkova, O.R., Historical and architectural environment as part of cultural heritage, Cultural heritage of the city of Saratov and the Saratov region, Materials of the 7th International Scientific and Practical Conference, Edited by Yu.Yu. Andreeva and I.E. Rakhimbaeva, 2018, P. 459-465.

[18] Pyatachenko, S.A., Karpenko, A.G., Potokina, T.M., Problems of preserving the cultural and historical appearance of Volgogra, New ideas of the new century: materials of the international scientific conference FAD TOGU, 2012, Vol. 1 P, 338-342.

[19] Mikhaleva, K.A., The current state and problems of preserving the architectural monuments of Kyakhta, Bulletin of the East Siberian State Academy of Culture and Arts, 2013, No. 1 (4), P. 113-116.

[20] Paramonova, L.S., Problems of studying, preserving and popularizing objects of historical and cultural heritage on the territory of the Jewish Autonomous Region, Territorial studies: goals, results and prospects. Abstracts of the VIII All-Russian School-Seminar for Young Scientists, Postgraduates and Students, 2015, P. 298-300.

[21] Talantbekova, Zh.T., Mamatov, Zh.Y., Restoration of architectural monuments, on the example of repair and restoration work of the building of the Pervomaisky district court, Bulletin of the Kyrgyz State University of Construction, Transport and Architecture named after I. N. Isanova, 2016, No. 2 (52), P. 138-143.

[22] Duzhik, D.D., Kozhnova, A.A., Modern multi-storey architecture in the context of the historical development of
Ryazan, Construction: science and education, 2019, Vol. 9, Issue. 2, Art. 7, Available at: http://nso-journal.ru. DOI: 10.22227 / 2305-5502.2019.2.7.

[23] Pankratova, A.A., Historical stone buildings in Ryazan: compositional features of facades, Vestnik MGSU, 2018, Vol. 13, Issue. 4 (115), P. 435-445.

[24] Pankratova,A.A., Soloviev, A.K., Problems of preservation and use of historical buildings in modern architecture of the city, Vestnik MGSU, 2015, No. 7, P. 7-16.

[25] Osina, N.A., Melnikova, E.N., The first stage in the study of wooden street buildings in the historical center of Ryazan, Science and education of the 21st century, Materials of the 11st International Scientific and Practical Conference, Modern technical university, 2017, P. 77-80.

[26] Osina, N.A., Zhuravleva, L.A., Chevagina, V.A., Coloristic solution of facades in the historical development of Ryazan, New technologies in the educational process and production. Materials of the XIII interuniversity scientific and technical conference, Edited by A.N. Parshin, 2015, P. 25-28.

[27] Knyazeva, M., Evtyukhina, D., Melnikova, V., Ryazan wooden architecture as a symbol of cultural heritage (on the example of a two-story urban development of the 19th century), Project Baikal, No. 61 (2019-08-29), P. 140-146, Available at: http://www.projectbaikal.com/index.php/pb/ar ticle/view/1517

[28] Sergey, V. Mokhovikov, Lydia V. Alekseenko, Marina V. Knyazeva, Igor A. Murog, Olesya S. Larina, Studies of cultural heritage sites of federal significance, Amazonia Investiga, Vol. 8, Núm. 21, Julio - Agosto, 2019, P. 296-306, Available at: https://www.amazoniainvestiga.info/index.ph p/amazonia/article/view/106

[29] Kozlova, N.I., The problem of preserving architectural monuments in terms of the concept of sustainable development, International scientific journal "Synergy of Sciences", 2017, No. S14, P. 104-108.

[30] Kolesnikov, V.I., The collection of architectural monuments and monumental art of Russia, State. Institute of Art Studies of the Ministry of Culture of the Russian Federation, Moscow: Science, 1998. (Collection of monuments of history and culture of Russia), Ryazan region: At 4 o'clock Part 1, Moscow: Indrik, 2012, 880 p.

[31] Bakushina, E.V., Zernova, E.A., Knyazev, M.V., Ryazan. Architectural monuments. Objects of cultural heritage of federal significance, Popular science publication, Ryazan: Zerna-Slovo, 2011, 164 p.

[32] Benhamou F. Heritage // A Handbook of Cultural Economics / Ed. by R. Towse. Cheltenham, UK; Northampton, MA, USA: Edward Elgar, 2010.

[33] Current problems of the economy of cultural heritage / Under the editorship of A. Ya., Rubinstein, M.: the State Institute of art studies. 2016. - 108 p. ISBN 978-5-98287-102-2. 